\title{
Immunocompetent Young Patient Presenting with Unilateral Lip Abscess Due to Peeling Exfoliated Lip Skin
}

\author{
Case Report $>$ (1) Deniz Esin Tekcan Şanl1 ${ }^{1,2}$, (1) Zerrin Boyac1 ${ }^{3}$ \\ ${ }^{1}$ Department of Medical Imaging Techniques, Vocational School of Health Services, İstanbul Rumeli University, \\ İstanbul, Turkey \\ ${ }^{2}$ Department of Radiology, Acıbadem Kozyatağı Hospital, İstanbul, Turkey \\ ${ }^{3}$ Department of Otorhinolaryngology, Acıbadem Kozyatağ 1 Hospital, İstanbul, Turkey
}

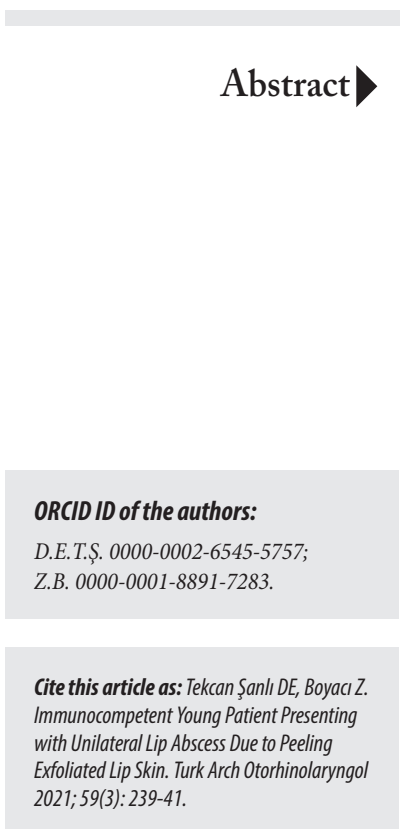

Corresponding Author: Deniz Esin Tekcan Şanli; tekcandenizesin@gmail.com

Received Date: 14.04 .2021 Accepted Date: 13.06 .2021

Content of this journal is licensed under a Creative Commons Attribution 4.0 International License. Available online at www.turkarchotolaryngol.net (c) (i) \$

DOl: $10.4274 / \operatorname{ta} 0.2021 .2021-4-9$

Lip abscess is a rare condition encountered in clinical practice. Generally, it may be due to an infective agent, such as virus, bacteria, entering through a skin wound, or it can be seen through hematogenous spread when there is a serious underlying condition such as a general condition disorder or immunodeficiency. It requires rapid diagnosis and treatment as it may cause significant complications in terms of localization and lymphovascular drainage. In this case report, an 18-year-old male patient with unilateral lip abscess that regressed rapidly with external drainage and antibiotic therapy is presented with imaging and clinical-laboratory findings.

Keywords: Lip, abscess, edema, lip abscess, immunocompetence, deep neck infection, case report

\section{Introduction}

Sudden painful lip swelling is a rare condition that we see in clinical practice. Lip swelling usually develops secondary to traumatic or allergic conditions. Infectious agents such as bacteria and viruses are the second most common cause of swollen lips (1). Herpes labialis or Herpes zoster should be considered especially in unilateral swelling accompanied by pain (2). In such viral infective cases, apart from systemic examination, the oral mucosa should also be examined, and the patient should be investigated for the presence of vesicles-ulcers $(3,4)$-Tumors of vascular origin such as hemangioma and lymphangioma or malignant tumors may also be the cause of swelling or asymmetric discoloration of the lips. In this case report, we aimed to provide clinicians a perspective in terms of lip swelling and lip infections by presenting the case of a young patient with unilateral lip abscess which regressed rapidly in a very short time with antibiotherapy and drainage.

\section{Case Presentation}

An 18-year-old male patient was admitted to our dermatology outpatient clinic with 
complaints of swelling, pain, redness in the right half of his lip. The patient who had widespread pustular acne on his face was questioned about his history of medication use, such as isoretinoic acid, that could cause infection by mucosal integrity loss. The patient stated that he did not use any medication. The patient, in whom empirical antibiotherapy and antiviral treatment (amoxicillin, valasiclovir) was initiated by the dermatology doctor, was admitted to the Ear-NoseThroat outpatient clinic three days after the increase in lip swelling and the onset of systemic complaints such as fever and weakness.

Physical examination revealed extremely edematous erythematous lips, more prominent in the right half of the lower lip, and multiple palpable lymphadenopathies (LAPs) in the right cervical chain (Figure 1a). In the evaluation of the oral and mucosal structures, there were no findings other than erythema and swelling on the lips. Initially, laboratory tests were requested to investigate infective causes and the patient was referred for ultrasonography. In ultrasonographic examination, diffuse thickening, more prominent in the right half of the lip, and marked increase in vascularity, as well as a heterogeneous non-locular collection with a dense content compatible with abscess was observed (Figures 2ab). Multiple LAPs with thickened cortex were detected in the right cervical chain at levels 1-2-3-4. Linear effusions consistent with edema were observed in the right half of the face and around the lips under the skin. Allergic causes were not expected since the patient's complaints had onset only three days ago, but immunological tests were also requested. However, when findings in favor of an abscess were described in ultrasonographic examination, the tests were canceled to focus on infection. Culture antibiogram was not taken since empirical antibiotherapy had already been started and the patient was using antibiotics for three days. In laboratory tests, leukocytosis $(15.8 \times 10 \mu \mathrm{L})$ was detected in neutrophil

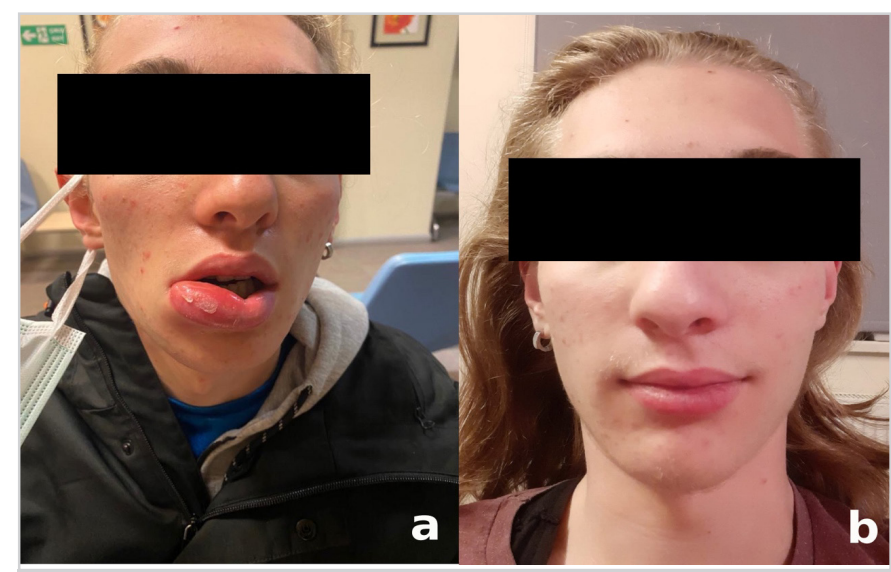

Figure 1a. Extremely edematous and erythematous appearance in the right lateral of the lower lip. Note the desquamation and peeling of the lip skin. b. View of lip that quickly returned to normal on the 3rd day of treatment dominance (80\%) with erythrocyte sedimentation rate (ESR: $41 \mathrm{~mm} / \mathrm{h}$ ) and high CRP $(7.5 \mathrm{mg} / \mathrm{dL})$. While HSV 1, HSV 2, VZV IgG antibodies were positive, IgM antibodies were negative. The patient stated that he had been picking and peeling his dried lips for a long time. The condition of the patient-who had no known chronic disease-was then evaluated as a primary lip abscess due to exfoliating his lips. Drainage was performed with a syringe, and about $10 \mathrm{cc}$ of pus was evacuated and intravenous antibiotic treatment (sultamicillin), oral antibiotics (amoxicillin) and antiviral therapy (valasiclovir) were continued for two days. Complaints of the patient, who also had spontaneous drainage during follow-up, regressed almost completely within three days and the lip returned to its normal state (Figure 1b). The patient provided his signed informed consent for publishing his data and images.

\section{Discussion}

In this case report we present a very rare cause of lip swelling in the form of a lip abscess that was detected in a young patient with localized involvement, together with clinical, laboratory, imaging findings. We emphasize the path to follow in differential diagnosis, follow-up and treatment. Viral agents such as Herpes and Varicella, which frequently affect the mouth and the face, are among the most common infective causes of lip swelling (2). Pain is more prominent than swelling and redness, especially in Herpes zoster. Cases can even be confused with trigeminal neuralgia (5). In these

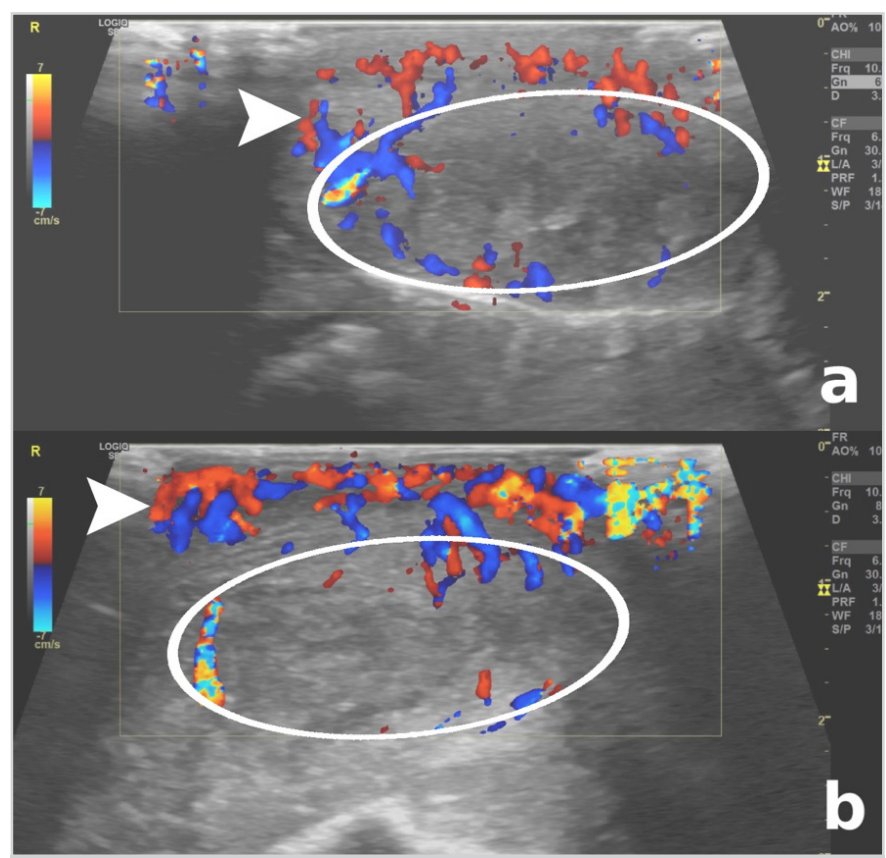

Figure 2a. In the ultrasonographic examination of the lip, a marked increase in lip thickness, a heterogeneous collection with a dense content compatible with abscess in the central part (circles), and b. increased vascularity in the periphery with Doppler sonography are observed (arrowheads) 
cases, vesicles-ulcers should be sought in the oral mucosa or the face during physical examination.

Bacterial agents such as Staphylococcus aureus may also cause lip swelling with or without lip abscess $(1,6)$. Bacterial infections should be kept in mind especially in immunocompromised patients who also have systemic complaints and rapidly progressive bacterial lip swelling. Primary-isolated lip abscess is an extremely rare condition and usually develops in an acute-rapidly progress secondary to bacterial agents. With a very rapid increase in lip sizes, it may lead to necrosis due to vascularization insufficiency (1). The lip becomes very swollen and erythematous, which can be confused with angioedema (7). Angioedema is important in differential diagnosis as it is an immunological entity that causes diffuse edema, progresses very rapidly and can lead to vital consequences, therefore requiring urgent intervention. Skin defects on the lips or face cause infection in soft tissues by opening the entrance door for these agents. In immunocompromised cases, it may spread to the face and neck region and cause deep neck infection (7). Therefore, lip abscess, like other bacterial infections in the head-neckface region, is a serious problem in terms of complications and mortality, and requires timely and accurate medical intervention.

In the literature, there are reports about cases presenting in the adolescent age group with lip abscesses caused by isotretinoin which is frequently used in the treatment of acne (8). Isotretinoin creates a predisposition for bacterial entry by creating skin dryness and cracks, especially around the lips. Likewise, a rapidly developing lip abscess secondary to an insect bite was reported in a young patient (9). Our case differs from other reported cases in that there was no risk factor.

To conclude, lip infections should be considered in patients with acute lip swelling, and bacterial-suppurative abscesses should be ruled out in rapidly developing conditions. In such acute and rapidly progressing situations, it is crucial to drain the abscess detected in imaging or examination without delay, initiate intravenous antibiotherapy, and obtain culture before antibiotherapy for rapid and specific treatment. With the timely and correct medical approach, it is possible to prevent complications that may even lead to mortality such as deep neck infections.

Informed Consent: The patient provided his signed informed consent for publishing his data and images.

Peer-review: Externally peer-reviewed.

Conflict of Interest: No conflict of interest was declared by the authors.

Financial Disclosure: The authors declared that this study received no financial support.

\section{Authorship Contributions}

Surgical and Medical Practices: D.E.T.Ş., Z.B., Concept: D.E.T.Ş., Design: D.E.T.Ş., Data Collection and/or Processing: D.E.T.Ş., Z.B., Analysis and/or Interpretation: D.E.T.Ş., Z.B., Literature Search: D.E.T.Ş., Z.B., Writing: D.E.T.Ş.

\section{Main Points}

- Unilateral lip abscess is a rare clinical condition.

- The clinical situation regresses rapidly with early drainage and antibiotic therapy.

- Serious progresses up to deep neck infection may occur in case of delay in treatment.

\section{References}

1. Amin D, Satishchandran S, Drew S, Abramowicz S. Diagnosis and treatment of lip infections. J Oral Maxillofac Surg 2021; 79: 13340. [Crossref]

2. Mambetsariev N, Patel A, Peters A. M159 Lip swelling as an early presentation of disseminated varicella zoster infection. Ann Allergy Asthma Immunol 2020: 125; S70. [Crossref]

3. Rosebush MS, Anderson KM, Rawal YB. Benign infectious lesions/conditions of the oral mucous membrane. Available at: https:/www.intechopen.com/books/diagnosis-and-managementof-oral-lesions-and-conditions-a-resource-handbook-for-theclinician/benign-infectious-lesions-conditions-of-the-oralmucous-membrane [Crossref]

4. Alciato L, Bonfils P, Rubin F. Unilateral oral, pharyngeal and laryngeal vesicles. Eur Ann Otorhinolaryngol Head Neck Dis 2019; 136: 141-2. [Crossref]

5. Efeoğlu C, Günbay S. Oral Zona zoster. Turkiye Klinikleri J Dental Sci 2010; 16: 203-6. [Crossref]

6. Godoy-Gijón E, del Pozo-de Dios JC, Román-Curto C. Absceso bacteriano labial en paciente inmunocompetente [Bacterial lip abscess in an immunocompetent patient]. Dermatol Online J 2013; 19: 13. [Crossref]

7. Bryan, YF, Kathleen NJ. The difficult airway in adults with angioedema. Available at: https://www.anesthesiologynews.com/ PRN-/Article/08-18/The-Difficult-Airway-in-Adults-WithAngioedema/52480 [Crossref]

8. Huoh KC, Chang KW. Lip abscess associated with isotretinoin treatment of acne vulgaris. JAMA Dermatol 2013; 149: 960-1. [Crossref]

9. Gupta SV, Lohe VK, Bhowate RR, Soni TN, Banode A. Lip abscess due to insect bite- A case report. J Oral Med Surg 2017; 1: 27-9. [Crossref] 